\title{
Perceptions of Parents of Children With Cancer About Medications Errors
}

\section{Kanserli Çocuğu Olan Ebeveynlerin İlaç Hatalarına İlişkin Algıları}

\author{
(D) Elif Bilsin'1, () Hatice Bal Yılmaz², (1) Gülçin Özalp Gerçeker3, (1) Şeyda Binay², \\ (1) Zümrüt Başbakkal'2, (D) Mehmet Kantar ${ }^{4}$ \\ ${ }^{1}$ Gaziantep University, Health Science Faculty, Şahinbey, Gaziantep, Turkey \\ ${ }^{2}$ Ege University, Nursing Faculty, Bornova, Izmir, Turkey \\ ${ }^{3}$ Dokuz Eylül University, Nursing Faculty, Bornova, Izmir, Turkey \\ ${ }^{4}$ Ege University, Medical Faculty, Bornova, Izmir, Turkey
}

\begin{abstract}
Aim: To evaluate perceptions of parents of children with cancer about medications errors.

Material and Method: The sample of the study with a crosssectional descriptive design consisted of parents of 100 children with cancer who received chemotherapy treatment. "The Parents' Perceptions of Drug Application Security," "The Methods Used by Parents to Protect Their Children from Medication Errors," and "The Parents' Willingness and Attitudes Toward Collaboration with Health Care Professionals" was used to collect research data.

Results: It was found that $7 \%$ of the parents confronted with a real medication error; of these, 3\% medication errors occurred in the form of wrong drug administration. It was also determined that $68 \%$ of the parents thought about the possibility of a medication error occurring during their children treatment. The parents responded as "yes" with the corresponding percentage to the following statements: "I always ask the nurse check whether the drug that he/she will administer on my child is the right drug" (37\%), "I trust doctors/nurses, so I do not check them" (61\%), and "If I encounter with a wrong drug administration, I definitely report it to the relevant authorities" (92\%).

Conclusions: The participant parents' awareness of the methods to protect their children from medication errors was found to be inadequate in some applications, but adequate in some others. It was also determined that they were willing to cooperate with health care professionals against medication errors.
\end{abstract}

Keywords: Medication errors; child; cancer; parents; perception
Öz

Amaç: Ilaç hataları, tıbbi hataların en sık görülen önlenebilir nedenidir. Pediatrik popülasyonda erişkinlerden daha sık görülür ve daha zararlıdır. Bu çalışmanın amacı kanserli çocuğu olan ebeveynlerin ilaç hatalarına ilişkin algılarını değerlendirmektir.

Gereç ve Yöntem: Kesitsel tanımlayıcı tipteki araştırmanın örneklemini kemoterapi tedavisi gören 100 kanserli çocuğun ebeveyni oluşturmuştur. Araştırma verilerinin toplanmasında "Ebeveynlerin İlaç Uygulama Güvenliği Algısı, İlaç Uygulama Hatalarından Çocuğu Korumak Iç̧in Kullandığı Yöntemler ve Sağlık Çalışanlarıyla Iş̧birliğine Iliş̧kin İsteği ve Tutumlarına" ilişkin bir anket kullanımıştır.

Bulgular: Ebeveynlerin \%7'sinin gerçek bir ilaç hatası ile karşılaştığı, karşılaşılan ilaç hatasının \%3'ünün yanlış ilaç olduğu saptanmıştır. Ebeveynlerin \%68'inin tedavisi sırasında ilaç hatası oluşma ihtimalini düşündüğü saptanmıştır. Ebeveynlerin \%37'sinin hemşireye çocuğuma uygulayacağı ilacın doğru ilaç olduğunu kontrol edip etmediğini sorarım, \%61'inin doktorlara/hemşirelere güveniyorum, onları kontrol etmem, \%92'sinin ilaç uygulaması sırasında bir hataya tanık olduğum zaman rapor ederim ifadelerine evet cevabı verdikleri belirlenmiştir.

Sonuç: Ebeveynlerin ilaç uygulama hatalarından çocuğu korumak için kullanılan yöntemlere ilişkin farkındalıklarının bazı uygulamalarda yetersiz iken bazılarında yeterli olduğu, ilaç uygulama hatalarına karşı sağlık çalışanlarıyla işbirliğine istekli oldukları saptanmıştır.

Anahtar Kelimeler: Ilaç hatası; çocuk; kanser; ebeveyn; algı. 


\section{INTRODUCTION}

Medication errors are the most common preventable cause of medical errors. No decline in the frequency of these errors has been noted over the past decade despite a large number of recommendations to prevent them. ${ }^{[1]}$ Different studies have found different rates of medication errors. ${ }^{[2-8]}$ The differences between these rates are due to differences in medication administration route (oral, intravenous, etc.), type of medicine and population being studied (adult, child). ${ }^{[4]}$ According to the National Coordinating Council for Medication Error Reporting and Prevention (NCC MERP), a medication error is defined as any preventable event that causes damage to the patient or leads to the use of inappropriate medication, although drug administration is under the control of a health professional, patient, or consumer. Medication errors can occur in any of the stages, including prescribing, packaging, labeling and administration. . $^{[1,4,6,9,10]}$

In addition to the potential errors in administering any drug, chemotherapy drugs are riskier due to the presence of a narrow therapeutic index, potential of developing toxicity even at therapeutic doses, and complexity of the treatment. Therefore, medication errors are observed at a much higher rate in the pediatric population, especially in oncology patients. Pediatric oncology patients are at risk twice due to the toxicity of chemotherapy drugs and immature development of children. ${ }^{[4]}$

According to the National Reporting and Learning System in England and Wales, 517.415 medication errors were reported between 2005 and 2010. This rate accounted for approximately $10 \%$ of all patient safety events in these countries. It was found that $16 \%$ of medication errors harmed the patients and $0.9 \%$ resulted in death or serious injury. Further, 50\% emerged in the form of wrong drug administration, $18 \%$ occurred during prescription, and $16 \%$ arose from neglect and delay in drug administration. ${ }^{[3]}$ Another study conducted in Switzerland found that 65 (3.5\%) of 1934 drug prescriptions were error. ${ }^{[5]}$

Medication errors are more common in, and harmful for, the pediatric population compared with adults. ${ }^{[1,4,12]}$ A major part of the preventable pediatric medication errors occurs during the drug administration phase. ${ }^{[6]}$ Therefore, nurses play an important role in the reduction and prevention of medication errors during drug administration. ${ }^{[1,13]}$ In addition, medication errors can be avoided through an active cooperation with caregivers of patient children by giving information to them about drug and drug administration (side effects of the drug, etc.), enabling them to participate in treatment process, and establishing an effective communication with them. $[1,9,13,14]$

Therefore, the aim of this study was to evaluate the perceptions of parents of children with cancer about medication errors and their relation to some sociodemographic variables.

\section{MATERIAL AND METHOD}

Type of the study is a cross-sectional descriptive. The population of the study consisted of parents of children with cancer who received chemotherapy treatment during the period March-May 2017 at a Pediatric Oncology and Children's Hospital Pediatric Hematology Clinics of a university hospital in Turkey. Pediatric Oncology Patients were encountered in a previous study was used..$^{[4]}$ In applying alpha .05 , power .80 on the $G$ power 3.1 software, sample size was calculated as a total of 93. The sample of the study consisted of 100 children with cancer who received chemotherapy treatment at specified clinics and period. Inclusion criteria for the caregivers were (a) being a primary caregiver parent and voluntary participation, (b) having a child who received chemotherapy treatment for at least 1 month, (c) being informant of the child's medical treatment, (d) being able to read and write in Turkish, (e) having received a written informed consent form. Parents refusing to participate in the study excluded from the survey.

The necessary permits to conduct the research were obtained from the Scientific Ethics Committee in Ege University Nursing Faculty (Approval no. 2015-77) and the institutions where the study was conducted. The researchers informed the participant caregivers about the purpose and process of the study, and then received their written informed consents for participating in the study.

\section{Measures and instruments}

"Demographic form" and "The Evaluation Form for Parents' Perceptions of Medication Errors" were used to collect research data.

\section{Demographic form}

This form included questions about the caregiver's and child. Evaluation form for parents' perceptions of medication errors Evaluation Form for Parents' Perceptions of Medication Errors:This form was prepared by reviewing the relevant literature. ${ }^{[4,15]}$ The form was composed of three parts: "The Parents' Perceptions of Drug Application Security," "The Methods Used by 
Parents to Protect Their Children from Medication Errors," and "The Parents' Willingness and Attitudes toward Collaboration with Health Care Professionals."

The Parents' Perceptions of Drug Application Security section consisted of six questions that were answered as "open-ended and yes or no" for the parents to answer concerning the following issues: condition of encountering a medication error, type of the encountered medication error, complications developed as a result of medication error, methods used to protect against medication errors, possibility of medication error during treatment, side effects of the drug, and state of anxiety about medication error, as well as seven questions that were answered as "yes or no" for receiving parents' statements about nurses and medication errors.

The Methods Used by Parents to Protect Their Children from Medication Errors section consisted of 18 questions that were answered as "yes or no" for receiving the information about the methods that the parents used for protecting their children from medication errors.

The Parents' Willingness and Attitudes toward Collaboration with Health Care Professionals section consisted of four questions that were answered as "yes or no" for the evaluation of the parents' willingness and attitudes toward collaboration with health care professionals to protect their children from medication errors. The questionnaire was applied to the parents using the face-to-face interview technique.

\section{Data analysis}

All data obtained through the Evaluation Forms for Parents' Perceptions of Medication Errors were analyzed in the SPSS 22.0 program using descriptive statistical variables such as mean, number, percentage, and chisquare test.

\section{RESULTS}

\section{Sociodemographic variables}

According to the sociodemographic characteristics of both children and parents, the participant parents had a mean age of $35.89 \pm 7.15$ years; of these parents, $92 \%$ were mothers, $37 \%$ were primary school graduates, $69 \%$ were housewives, $51 \%$ had income equal to expense, and $41 \%$ had 2 children. Furthermore, the cancerdiagnosed children had a mean age of $7.41 \pm 5.41$ years, and of them, $67 \%$ were males, $63 \%$ were diagnosed with acute lymphoblastic leukemia, and $24 \%$ were relapsed. The mean time between the dates of diagnosis and data collection was $9.67 \pm 10.83$ months, and the mean chemotherapy week was $18.62 \pm 14.76$ (Table 1 ).
Table 1. The Sociodemographic characteristics of both children and parents

\begin{tabular}{|c|c|c|}
\hline The sociodemographic characteristics & $\mathbf{N}$ & $\%$ \\
\hline \multicolumn{3}{|l|}{ Gender of the parent } \\
\hline Mother & 92 & 92 \\
\hline Father & 8 & 8 \\
\hline Mean age of parents & \multicolumn{2}{|c|}{$35.89 \pm 7.15$} \\
\hline \multicolumn{3}{|l|}{ Parents' educational status } \\
\hline Graduate of primary school & 37 & 37 \\
\hline Graduate of high-school or equivalent & 37 & 37 \\
\hline $\begin{array}{l}\text { Graduate of a faculty/higher education } \\
\text { institution }\end{array}$ & 26 & 26 \\
\hline \multicolumn{3}{|l|}{ Parent's occupation } \\
\hline Housewives & 69 & 69 \\
\hline Employee & 18 & 18 \\
\hline State official & 13 & 13 \\
\hline \multicolumn{3}{|l|}{ Income level } \\
\hline Income more than expense & 12 & 12 \\
\hline Income equal to expense & 51 & 51 \\
\hline Income not covering expense & 37 & 37 \\
\hline \multicolumn{3}{|l|}{ Number of children in the family } \\
\hline 1 & 40 & 40 \\
\hline 2 & 41 & 41 \\
\hline 3 & 14 & 14 \\
\hline 4 & 5 & 5 \\
\hline Mean age of children & \multicolumn{2}{|c|}{$7.41 \pm 5.41$} \\
\hline \multicolumn{3}{|l|}{ Gender of the children } \\
\hline Female & 33 & 33 \\
\hline Male & 67 & 67 \\
\hline \multicolumn{3}{|l|}{ Types of cancer } \\
\hline Acute lymphoblastic leukemia & 63 & 63 \\
\hline Acute myeloid leukemia & 11 & 11 \\
\hline Brain tumor & 9 & 9 \\
\hline Lymphoma & 3 & 3 \\
\hline Other & 14 & 14 \\
\hline \multicolumn{3}{|l|}{ Relapse status } \\
\hline Yes & 24 & 24 \\
\hline No & 76 & 76 \\
\hline $\begin{array}{l}\text { The mean time between the dates of diagnosis } \\
\text { and data collection (month) }\end{array}$ & \multicolumn{2}{|c|}{$9.67 \pm 10.83$} \\
\hline The mean chemotherapy week & \multicolumn{2}{|c|}{$18.62 \pm 14.76$} \\
\hline
\end{tabular}

\section{Parents' perceptions of drug application security}

It was determined that $7 \%$ of parents confronted with a real medication error, and of these medication errors, $3 \%$ were due to wrong drug administration. Also, $65 \%$ of parents made an attempt to protect their children from medication errors, $68 \%$ thought of the possibility of medication error during treatment, $87 \%$ would still like to follow the side effects of the drug even if they were explained about the side effects of the drug, and $46 \%$ were sometimes concerned about the likelihood of medication error (Table 2). 
Table 2. Parental perceptions of drug application security

\begin{tabular}{|c|c|c|}
\hline & $\mathbf{N}$ & $\%$ \\
\hline \multicolumn{3}{|l|}{ A case of encountering with a real medication error } \\
\hline Yes & 7 & 7.0 \\
\hline No & 93 & 93.0 \\
\hline \multicolumn{3}{|l|}{ The encountered medication errors } \\
\hline Wrong drug & 3 & 3.0 \\
\hline Wrong drug dose/amount & 1 & 1.0 \\
\hline $\begin{array}{l}\text { Development of phlebitis due to insufficient } \\
\text { hygiene }\end{array}$ & 2 & 2.0 \\
\hline \multicolumn{3}{|l|}{$\begin{array}{l}\text { Any attempt by the parent to protect the child } \\
\text { against medication errors }\end{array}$} \\
\hline Yes & 65 & 65.0 \\
\hline No & 34 & 34.0 \\
\hline \multicolumn{3}{|l|}{$\begin{array}{l}\text { Parental consciousness of the possibility } \\
\text { of medication error during treatment }\end{array}$} \\
\hline Yes & 68 & 68.0 \\
\hline No & 32 & 32.0 \\
\hline \multicolumn{3}{|l|}{$\begin{array}{l}\text { What would you do if you were told about } \\
\text { side effects of the medicine/drug? }\end{array}$} \\
\hline I refuse to give the medicine/drug to my child & 5 & 5.0 \\
\hline $\begin{array}{l}\text { I give the medicine/drug to my child and } \\
\text { then control side effects }\end{array}$ & 87 & 87.0 \\
\hline $\begin{array}{l}\text { I give the medicine/drug to my child without } \\
\text { worrying about side effects }\end{array}$ & 8 & 8.0 \\
\hline \multicolumn{3}{|l|}{$\begin{array}{l}\text { Parent's worry about the likelihood of } \\
\text { medication error }\end{array}$} \\
\hline Never & 14 & 14.0 \\
\hline Sometimes & 46 & 46.0 \\
\hline Always & 40 & 40.0 \\
\hline
\end{tabular}

\section{Parents' statements about nurses and medication errors}

The parents gave the answer of "yes" to the following statements about nurses and medication errors with the corresponding percentage: "Nurses do everything to prevent an error" (84\%), "Nurses inform me about the medication error" (59\%), "Nurses inform me about what to do to prevent an error" (80\%), "Nurses carry out drug administration carefully and meticulously" (92\%), "Nurses wash their hands before drug administration" (73\%), "Nurses show me drug name before drug administration" (49\%), and "Nurses inform me about chemotherapy treatment plan" (59\%) (Table 3).
Table 3. Expressions about nurse and medication errors

\begin{tabular}{lcccc} 
& \multicolumn{2}{c}{ Yes } & \multicolumn{2}{c}{ No } \\
\cline { 2 - 5 } & N & $\%$ & N & $\%$ \\
\hline $\begin{array}{l}\text { Nurses do everything to } \\
\text { prevent an error }\end{array}$ & 84 & 84.0 & 16 & 16.0 \\
$\begin{array}{l}\text { Nurses inform me about the } \\
\text { medical error }\end{array}$ & 59 & 59.0 & 41 & 41.0 \\
$\begin{array}{l}\text { Nurses inform me about what } \\
\text { to do to prevent an error }\end{array}$ & 80 & 80.0 & 20 & 20.0 \\
$\begin{array}{l}\text { Nurses carry out drug administration } \\
\text { carefully and meticulously }\end{array}$ & 92 & 92.0 & 8 & 8.0 \\
$\begin{array}{l}\text { Nurses wash their hands before } \\
\text { drug administration }\end{array}$ & 73 & 73.0 & 27 & 27.0 \\
$\begin{array}{l}\text { Nurses show me drug name } \\
\text { before drug administration }\end{array}$ & 49 & 49.0 & 51 & 51.0 \\
$\begin{array}{l}\text { Nurses inform me about } \\
\text { chemotherapy treatment plan }\end{array}$ & 59 & 59.0 & 41 & 41.0 \\
\hline
\end{tabular}

\section{Methods used by the parents to protect their children from medication errors}

The parents gave the answer of "yes" to the following statements about the methods they used for protecting their children from medication errors, with the corresponding percentage; "I ask the nurse whether he/ she has washed his/ her hands" (15\%), "I ask the drug name and dose" (73\%), "I ask nurse check whether the drug that he/she will apply to my child is the right one" (37\%), "I check my child's name on the injector or drug to be applied" (77\%), "I follow whether the nurse checks my child's name on the wristband before giving the medication" (66\%), "I check whether the drug is being administered at the right time" (80\%), "I pay attention whether the drugs are given in an appropriate way either directly from the mouth or from the vein" (87\%), "I pay attention whether the nurse checks the vascular access before drug administration" (80\%), "I pay attention to the number, color and appearance of the medication, and report the aband stop drug administration to ask it to the nurse" (78\%), "I ask the doctor/nurse to give more information about the drug" (84\%), "I ask the doctor/ nurse to explain the chemotherapy treatment plan" (89\%), "I follow the chemotherapy treatment program" (92\%), "I ask the doctor/nurse to inform me about the changes in treatment plan" (97\%), "I ask the nurse to inform me when he/she makes a medication error" (98\%), and "I trust doctors/nurses, and do not check them" (61\%) (Table 4). 


\begin{tabular}{|c|c|c|c|c|}
\hline & \multicolumn{2}{|c|}{ Yes } & \multicolumn{2}{|c|}{ No } \\
\hline & $\mathbf{N}$ & $\%$ & $\mathbf{N}$ & $\%$ \\
\hline I ask the nurse whether he/she has washed his/her hands & 15 & 15.0 & 85 & 85.0 \\
\hline I ask the name and dose of the medicine/ drug & 73 & 73.0 & 27 & 27.0 \\
\hline I ask the nurse check whether the drug that he/she will apply to my child is the right one & 37 & 37.0 & 63 & 63.0 \\
\hline I check the name of my child on the injector or medication & 77 & 77.0 & 23 & 23.0 \\
\hline I follow whether the nurse checks my child's name on the wristband before giving the medication & 66 & 66.0 & 34 & 34.0 \\
\hline I check whether the drug is being administered at the right time & 80 & 80.0 & 20 & 20.0 \\
\hline $\begin{array}{l}\text { I pay attention whether the drugs are given in an appropriate way either directly from the mouth or } \\
\text { from the vein }\end{array}$ & 87 & 87.0 & 13 & 13.0 \\
\hline I pay attention whether the nurse checks the vascular access before drug administration & 80 & 80.0 & 20 & 20.0 \\
\hline $\begin{array}{l}\text { I pay attention to the number, color, and appearance of the medication, and report the abnormal } \\
\text { situations to the nurse }\end{array}$ & 93 & 93.0 & 7 & 7.0 \\
\hline I report the symptoms and side effects occurring after treatment & 98 & 98.0 & 2 & 2.0 \\
\hline I check and report errors & 89 & 89.0 & 11 & 11.0 \\
\hline $\begin{array}{l}\text { I check the medication again when I suspect that there is a medication error and stop drug } \\
\text { administration to ask the nurse }\end{array}$ & 78 & 78.0 & 22 & 22.0 \\
\hline I ask doctor/nurse to give more information about the drug & 84 & 84.0 & 16 & 16.0 \\
\hline I ask doctor/nurse to explain the chemotherapy treatment plan & 89 & 89.0 & 11 & 11.0 \\
\hline I follow the chemotherapy treatment program & 92 & 92.0 & 8 & 8.0 \\
\hline I ask doctor/nurse to inform me about the changes in treatment plan & 97 & 97.0 & 3 & 3.0 \\
\hline I ask the nurse to inform me when he/she makes a medication error & 98 & 98.0 & 2 & 2.0 \\
\hline I trust doctors/nurses and do not check them & 61 & 61.0 & 39 & 39.0 \\
\hline
\end{tabular}

\section{Parents' willingness and attitudes toward collaboration with health care professionals to protect their children from medication errors}

The parents gave the answer of "yes" to the following statements evaluating their willingness and attitudes toward collaboration with health care professionals to protect their children from medication errors, with the corresponding percentage; "I do not want my child to be exposed to medication errors" (99\%), "I am willing to protect my child from medication errors" (98\%), "I report any medication error that I witness" (92\%), and "I want to learn more about prevention of medication errors" (96\%) (Table 5).

Relation of parents' perceptions of medication errors with their education status and number of chemotherapy weeks No significant difference was found between the parents' drug application security perceptions in terms of the variables including education status, number of the child's chemotherapy weeks, their statements about nurses and medication errors, methods they used for protecting their children from medication errors, and their willingness and attitudes toward collaboration with health care workers to protect their children from medication errors ( $p>$.05).
Table 5. Parents' willingness and attitudes toward collaboration with health care workers to protect their children from medication errors

\begin{tabular}{lcccc} 
& \multicolumn{2}{c}{ Yes } & \multicolumn{2}{c}{ No } \\
\cline { 2 - 5 } & N & $\%$ & N & $\%$ \\
\hline $\begin{array}{l}\text { I do not want my child to be exposed to } \\
\text { medication errors }\end{array}$ & 99 & 99.0 & 1 & 1.0 \\
$\begin{array}{l}\text { I am willing to protect my child from } \\
\text { medication errors }\end{array}$ & 98 & 98.0 & 2 & 2.0 \\
$\begin{array}{l}\text { I report/inform about any medication } \\
\text { error that I witness }\end{array}$ & 92 & 92.0 & 8 & 8.0 \\
$\begin{array}{l}\text { I want to learn more about prevention } \\
\text { of medication errors }\end{array}$ & 96 & 96.0 & 4 & 4.0 \\
\hline
\end{tabular}

\section{DISCUSSION}

Pediatric chemotherapy medication errors are usually harmful to the patient. $^{[8]}$ In addition to medication errors in the hospital, parents are also reported making mistakes in calculating drug doses at home. ${ }^{[9,16]}$

The medication errors reported by health care professionals were higher than those reported by parents. This was due to the fact that most of the medication errors in the hospital were reported to the patients and their families. ${ }^{[6]}$ 
On examining studies of medication error rates and causes reported by health care professionals, Özkan et al. ${ }^{[7]}$ reported that the medication error rate in general pediatric clinics was $28.2 \%$, and time and dose errors were made at most in the drug administration process. Rinke et al. ${ }^{[8]}$ reported that $15.6 \%$ of pediatric chemotherapy medication errors required a follow-up or treatment procedure for the relevant patients, and $40 \%$ occurred during the application phase. Büyük et al. ${ }^{[2]}$ found that pediatric chemotherapy medication errors included incorrect written orders, skip of drug dose, nonregistration of drug administrations, improper drug administration, and administration of incorrect drug dose. Lan et al. ${ }^{[6]}$ found that $60 \%$ of pediatric medication errors were wrong doses, resulting in serious medical problems in $9.2 \%$ of patient children.

On examining studies of medication errors rates reported by parents, Lan et al. ${ }^{[6]}$ reported that $7.1 \%$ of parents experienced at least one medication error during the treatment of their children. Harris et al. ${ }^{[4]}$ reported that $5 \%$ of parents met a medication error during chemotherapy. This present study, in line with the literature, also reported that $7 \%$ of the parents met a real medication error during their patient children's treatment process. Also, this study found that $3 \%$ of the medication errors were related to the use of wrong drugs, parents thought of the possibility of medication error during treatment, and they would still like to follow the side effects of the drug even if they were explained about these side effects. Harris et al. ${ }^{[4]}$ showed that $73 \%$ of parents made an attempt to protect their child against a medication error, $86 \%$ would still like to follow the side effects of the drug even if they were explained about these side effects, and 33\% thought of the possibility of medication error during treatment. Schwappach \& Wernli ${ }^{[15]}$ conducted a study on adult patients receiving adult chemotherapy and found that $55.3 \%$ of them were concerned about medication errors. However, studies on parents' perception of medication errors in the pediatric cancer population are limited. ${ }^{[4]}$

Nurse's role in drug management has improved considerably in recent years. In drug management, a nurse has roles such as drug dosage calculation, drug control and administration, and patient evaluation, registration, and training. ${ }^{[17]}$ Nurses have an important position in reducing and preventing medication errors because they are the last health care professional checking drugs to determine medication errors in the course of drug administration.
The recommended measures and practices for nurses in reducing drug administration errors include safe delivery of medicines, preparation, control, and implementation of the correct medication, and informing of the child and family. The nurses are held responsible for the information to parents. It is important for nurses to give verbal and written information to parents about the drug effects and side effects to reduce medication errors. ${ }^{[13]}$ Some studies stated that parental education could reduce medication errors. ${ }^{[18,19]}$ According to Schwappach \& Wernli ${ }^{[15]} 51.2 \%$ of patients were informed by the doctor/ nurse in the case of a medication error, $88.2 \%$ believed in that the doctor/nurse works extremely carefully, $88.3 \%$ reported that the doctor/nurse had disinfected his/her hands before drug administration, $68.6 \%$ also reported that the doctor/nurse had shown the label of the medication bag before the infusion was started, and $61.7 \%$ stated that they saw the chemotherapy protocol. The findings of the present study were as follows: most of the nurses had carefully and rigorously applied the medication to prevent a failure, informed the parents about what to follow to prevent a medication error, and washed their hands before drug administration. Also, almost half of them had informed the parents about the medication errors, showed them the drug name before administration, and explained the chemotherapy treatment plan.

Parents should be informed about drug administration, enabled to participate in drug administration, and encouraged to express their concerns in drug administration to prevent medication errors in children. Also, drug administration should be reviewed, and the relevant drug should be checked twice. ${ }^{[13,22]}$ However, despite the double check, medication errors still occur. The supported and motivated parents help develop safe medication practices. $\left.{ }^{[23}\right]$ Therefore, including parents in the drug administration and control process is one of the security measures to be taken to protect children from medication errors. ${ }^{[4,20]}$ Harris et al. ${ }^{[4]}$ examined the methods parents used to protect their children from medication errors and obtained the following results; $61 \%$ of parents asked the drug name and dose, $60 \%$ checked whether his/her child's name was present on the injector or drug, $63 \%$ controlled the chemotherapy treatment protocol, $46 \%$ asked the doctor/nurse to give more information about the drug, $70 \%$ noted whether the nurse had checked his/her child's name on the wristband before giving the medication, and $56 \%$ paid attention whether the nurse had checked the vascular pathway before administering the drug. 
Schwappach \& Wernli ${ }^{[15]}$ found that $14.1 \%$ of parents asked the nurse about the drug name and dose, and $16.2 \%$ monitored medication errors. These results indicated that the methods parents used to protect their children from medication errors were inadequate. The present study found that parents were inadequate to monitor whether the nurse had washed his/her hands before administering the medication, whether the drug was the right drug, and whether the nurse had checked the child's wristband before giving the medicine.

Teamwork and cooperation are needed in drug administration. ${ }^{[17]}$ The communication between patient and health care professionals reduces medication errors. ${ }^{[24]}$ In the present study, parents were found to be willing to cooperate with health care providers against medication errors. In another study, $96 \%$ of parents were found to be willing to protect their children from medication errors. ${ }^{[4]}$ The present study results were found to be consistent with the literature.

In the present study, no significant difference was found between the parents' drug application security perceptions in terms of their education status, number of the child's chemotherapy weeks, their statements about nurses and medication errors, methods they used for protecting their children from medication errors, and their willingness and attitudes toward collaboration with health care professionals to protect their children from medication errors ( $p>.05)$. Harris et al. ${ }^{[4]}$ also found no significant difference between parents' willingness and attitudes toward collaboration with health care professionals to protect their children from medication errors in terms of their educational status, the time period during which the child was diagnosed with cancer, and the complexity of treatment. This result indicated that education alone was not sufficient. Therefore, health care professionals should train parents on drug administration regardless of their education levels, and the relevant training should be repeated.

\section{CONCLUSIONS}

The participant parents' awareness of the methods to prevent medication errors was found to be inadequate in some applications, but adequate in some others. It was also found that the parents were willing to cooperate with health care professionals against medication errors. Medication errors can be prevented by increasing parental perception about preventing medication errors. It is also suggested to conduct more extensive studies on parents' perception of medication errors using more parents and different pediatric populations.

\section{ETHICAL DECLARATIONS}

Ethics Comittee Approval: The study was carried out with the permission of local Ethics Committee in Ege University Nursing Faculty (Approval no. 2015-77)

Informed Consent: Because the study was designed retrospectively, no written informed consent form was obtained from patients.

Status of Peer-review: Externally peer-reviewed.

Conflict of Interest Statement: The authors have no conflicts of interest to declare.

Financial Disclosure: The authors declared that this study has received no financial support.

Author Contributions: All of the authors declare that they have all participated in the design, execution, and analysis of the paper, and that they have approved the final version.

\section{REFERENCES}

1. Gonzales K. Medication administration errors and the pediatric population: A systematic search of the literature. J Pediatr Nurs [Internet] Elsevier Inc.; 2010;25(6):555-65.

2. Büyük ET, Güdek E, Güney Z, Yıldırım S, Akkoca S. Chemotherapeutic Drug Administration Mistakes Experienced by Nurses Working in Pediatric Oncology Units. J Pediatr Res. 2014;1(4):207-11.

3. Cousins DH, Gerrett D, Warner B. A review of medication incidents reported to the National Reporting and Learning System in England and Wales over 6 years ( 2005 - 2010 ). Br J Clin Pharmacol. 2011;74(4):597604.

4. Harris N, Badr LK, Saab R, Khalidi A. Caregivers' perception of drug administration safety for pediatric oncology patients. J Pediatr Oncol Nurs [Internet]. 2014;31(2):95-103.

5. Hartel MJ, Staub LP, Röder C, Eggli S. High incidence of medication documentation errors in a Swiss university hospital due to the handwritten prescription process. BMC Health Serv Res [Internet]. BioMed Central Ltd; 2011;11(1):199.

6. Lan YH, Wang KWK, Yu S, Chen IJ, Wu HF, Tang FI. Medication errors in pediatric nursing: Assessment of nurses' knowledge and analysis of the consequences of errors. Nurse Educ Today [Internet]. Elsevier Ltd 2014;34(5):821-8.

7. Özkan S, Kocaman G, Öztürk C. Effect of strategies for preventing medication administration errors in pediatric inpatients. Turk Arch Ped. 2013;299-302.

8. Rinke ML, Shore AD, Morlock L, Hicks RW, Miller MR. Characteristics of pediatric chemotherapy medication errors in a national error reporting database. Cancer. 2007;110(1):186-95.

9. Chen CJ. Medication errors in pediatrics. Pediatr Neonatol [Internet] Elsevier Taiwan LLC; 2013;54(1):3-4.

10. U.S. Food and Drug Administration. Medication Errors Related to Drugs [Internet]. U.S. Food and Drug Administration. 2014 [cited 2015 Mar 30].

11. Guerrero-aznar MD, Jiménez-mesa E, Cotrina-luque J, Villalba-moreno A. Validation of a method for notifying and monitoring medication errors in paediatrics. An Pediatría (English Ed [Internet]. Asociación Española de Pediatría; 2014;81(6):360-7.

12. Törüner Kılıçarslan E, Erdemir F. Prevention of Medication Errors in Pediatric Patients. Hacettepe Üniversitesi Sağlık Bilim Fakültesi Hemşirelik Derg. 2010;63-71.

13. Uzun Ş, Arslan F. Medication Errors: Scientific Letter. Turkiye Klin J Med Sci. 2008;28(2):217-22. 
14. Schwappach DLB, Wernli M. Chemotherapy Patients' Perceptions of Drug Administration Safety. J Clin Oncol [Internet]. 2010;28(17):2896-901.

15. Anderson C, Rolfe P, Brennan-Hunter A. Administration of over-thecounter medication to children at home--a survey of parents from community health centers. J Community Health Nurs. 2013;30(3):143-54.

16. Leufer T, Cleary-holdforth J. Nurse Education in Practice Let's do no harm : Medication errors in nursing: Part 1. Nurse Educ Pract [Internet]. Elsevier Ltd; 2013;13(3):213-6.

17. Beckett VL, Tyson LD, Carroll D, Gooding NM, Kelsall AW. Accurately administering oral medication to children isn't child's play. Arch Dis Child. 2012;(97):838-41.

18. Li SF, Lacher B, Crain EF. Acetaminophen and ibuprofen dosing by parents. Pediatr Emerg Care. 2000;16(6):394-7.

19. Ghaleb M, Barber N, Franklin B, Yeung V, Khaki Z, Wong I. Systematic review of medication errors in pediatric patients. Ann Pharmacother. 2006;40:1766-1776.

20. Star K, Nordin K, Pöder U, Edwards IR. Challenges of safe medication practice in paediatric care A nursing perspective. Acta Paediatr Int J Paediatr. 2013;102(5):532-8.

21. Crawford D. Maintaining good practice in the administra tion of medicines to children. Nurs Child Young People. 2012;24(4):29-35; quiz 36.

22. Stebbing C, Wong ICK, Kaushal R, Jaffe A. The role of communication in paediatric drug safety. Arch Dis Child. 2007;92(5):440-5. 